\title{
UPAYA PENINGKATAN PEMAHAMAN GURU DALAM MENYUSUN LAPORAN PTK MELALUI PEMBIMBINGAN TERFOKUS DENGAN PENDEKATAN KOLABORATIF
}

\author{
Imam Setiyadi \\ Pengawas SMP Dinas Pendidikan Ketapang \\ Email: imamsetiyadi68@gmail.com
}

\begin{abstract}
Abstrak
Penelitian Tindakan Sekolah (PTS) ini berangkat dari permaslahan yang ada dilapangan khususnya di sekolah binaan, judul penelitian adalah "Upaya Peningkatan Pemahaman Guru Dalam Menyusun Laporan Penelitian Tindakan Kelas Melalui bimbingan Terfokus Dengan Pendekatan Kolaboratif di Sekolah Binaan". Penelitian ini dilaksanakan dengan tujuan sebagai berikut: (1) Secara umum, untuk meningkatkan pemahaman guru dalam menyusun laporan penelitian tindakan kelas, dalam rangka meningkatkan kualitas proses pembelajaran. (2) Secara khusus, untuk mendeskripsikan penerapan bimbingan terfokus dengan pendekatan kolaboratif dalam meningkatkan pemahaman dan kemampuan guru menyusun laporan penelitian tindakan kelas yang dilaksanakan oleh peneliti di sekolah binaan. Pengumpulan data dilakukan dengan menggunakan angket dan penilaian laporan hasil penelitian tindakan kelas dari guru yang menjadi subjek penelitian. Penelitian ini dilaksanakan dalam dua periode siklus tindakan, dengan menerapkan penjelasan secara kelompok dan bimbingan individu, dengan subyek penelitian 2 sekolah yang terdiri dari 11 orang guru di wilayah Sekolah binaan di Kabupaten Ketapang. Dari hasil penelitian tindakan sekolah terbukti adanya peningkatan pemahaman yaitu : Sebelum diberi penjelasan skor pemahaman guru 2,2 naik menjadi 3,4 setelah bimbingan secara kelompok, dan pada pembimbingan individu naik menjadi 3,57. Oleh karena itu dengan tidak memperhatikan kemungkinan lain yang bisa terjadi, maka hipotesa tindakan penelitian ini dapat diterima kebenarannya.
\end{abstract}

\section{Kata kunci: Kemampuan Guru, Penelitian Tindakan Kelas, Pembimbingan Terfokus, Pendekatan Kolaboratif.}

\section{PENDAHULUAN}

Pemberlakuaan Permenpan dan RB mendapatkan tanggapan beragam dari guru. Tanggapan tersebut antara lain ada yang menyambut gembira, namun sebagian besar menyambut dengan ktidak siapan. Ketidak siapan guru guru karena kemampuan dan waktu untuk melakukan penelitian dan menulis sangat terbatas. Sebagian besar guru pangkatnya berhenti pada golongan IV/a. Salah satu penyebabnya adalah karena tidak mampu membuat publikasi ilmiah, sebagaimana termaktub dalam Permenpan RB no 16 Tahun 2009 yang terdiri dari presentasi pada forum ilmiah, publikasi hasil penelitian, atau gagasan inovatif pada bidang pendidikan dan publikasi buku teks pelajaran, buku pengayaan dan/atau pedoman guru. Sebagian yang lain memanfaatkan lambatnya kenaikan pangkat guru setelah memasuki pangkat Pembina, golongan IV /a dengan mengadakan bimbingan penulisan publikasi ilmiah dan karya inovatif. Dimanfaatkannya kesempatan ini dapat disebabkan oleh bermacam-macam faktor, antara lain: Banyaknya guru yang pemahamannya pada publikasi ilmiah dan karya inovatif masih sangat rendah. Sebagian besar guru belum mengikuti pelatihan yang terkait dengan publikasi ilmiah dan karya inovatif. Rendahnya kemampuan guru dalam menyusun laporan hasil penelitian tindakan kelas. Motivasi baik dari kepala sekolah, maupun pengawas sekolah untuk melakukan kegiatan publikasi ilmiah dan karya inovatif. Tidak adanya sanksi bagi guru yang tidak melakukan publikasi ilmiah.

Sebagian guru masih menganggap bahwa PTK yang merupakan salah satu bentuk publikasi ilmiah sebagai karya yang sulit untuk dibuat, membutuhkan banyak biaya dan memakan waktu yang cukup lama. Berdasarkan pengamatan peneliti dan informasi dari para guru, bahwa rendahnaya kemampuan guru dalam melakukan publikasi ilmiah dan karya inovatif antara lain disebabkan oleh: (1) Kurangnya kesempatan guru untuk mendapatkan pelatihan untuk publikasi ilmiah dan karya inovatif; (2) Kurangnya bimbingan dari kepala 
sekolah/ pengawas sekolah tentang publikasi ilmiah dan karya inovatif; (3) Kurangnya motivasi untuk menulis, karena rendahnya tambahan penghasilan setelah naik pangkat yang dlam prosesnya membutuhnya anggaran yang cukup besar; (4) Guru merasa pada zona nyaman karena telah mendapatkan sertifikasi guru, sehingga walaupun tidak bertamah gajinya karena naik pangkat, tetapi mendapatkan sertifikasi, mereka sudah merasa cukup; (5) Tidak adanya sanksi bagi guru yang tidak melakukan publikasi ilmiah atau karya inovatif.

Permasalahan sebagaimana tersebut di atas mendorong peneliti untuk melakukan upaya peningkatan kemampuan guru. Berbagai pertimbangan dan mengingat tugas pokok dan fungsi pengawas sekolah adalah melakukan pembinaan guru, maka peneliti berupaya dengan menggunakan teknik pembimbingan terfokus dengan pendekatan kolaboratif untuk meningkatkan kemampuan guru menulis laporan penelitian tindakan kelas. Teknik ini dipilih mengingat dengan teknik ini, peneliti tidak hanya memberikan penjelasan, tetapi mendenger, mambantu dan membimbing guru mulai dari memahami permasalahan, membuat kerangka teori, memilih metode penelitian dan menuliskan penelitian yang dilaksanakannya.

Adapun Tujuan yang ingin dicapai dari kegiatan penelitian tindakan ini adalah : (1) Untuk medeskripsikan proses pembimbingan terfokus dengan teknik kolaboratif untuk meningkatkan pemahaman guru dalam menulis laporan PTK di Sekolah Binaan; (2) Untuk mengetahui peningkatan kemampuan guru dalam menulis laporan PTK dengan menggunakan pendekatan kolaboratif pembimbing terfokus disekolah binaan di Kabupaten Ketapang.

Pengertian pemahaman adalah kemampuan untuk menangkap makna dan arti dari bahan yang dipelajari (Winkel, 1996). Menurut Bloom dalam Winkel (1996) pemahaman termasuk dalam klasifikasi ranah kognitif level 2 setelah pengetahuan. Pengertian pemahaman dapat di urai dari kata "Faham" yang memiliki arti tanggap, mengerti benar, pandangan, ajaran. Disini ada pengertian tentang pemahaman yaitu Departemen Pendidikan Nasional. 2003. : kemampuan memahami arti suatu bahan diberikan/diajarkan, seperti menafsirkan , menjelaskan atau meringkas atau merangkum suatu pengertian kemampuan macam ini lebih tinggi dari pada pengetahuan. Pemahaman juga merupakan tingkat berikutnya dari tujuan ranah kognitif berupa kemampuan memahami atau mengerti tentang isi pembimbingan yang dipelajari tanpa perlu mempertimbangkan atau memperhubungkannya dengan isi pembimbingan lainnya. Dan pemahaman ini dapat dibagi 3 kategori yaitu (Muh.Arifin, 2010): (1) Tingkat Rendah: Pemahaman terjemah mulai dari terjemahan dalam arti sebenarnya semisal, Bahasa asing dan bahasa Indonesia; (2) Tingkat Menangah: Pemahaman yang memiliki penafsiran, yakni menghubungkan bagian-bagian terdahulu dengan diketahui beberapa bagian dari grafik dengan kejadian atau peristiwa; (3) Tingkat Tinggi: Pemahaman ekstrapolasi dengan ekstrapolasi yang diharapkan seseorang mampu melihat di balik, yang tertulis dapat membuat ramalan konsekuensi atau dapat memperluas resepsi dalam arti waktu atau masalahnya.

Pembimbingan terfokus sebagai kegiatan yang memfokuskan pada kegiatan khusus, sehingga kegiatan pembimbingan yang dilakukan hanya pada kegiatan yang diteliti. Kegiatan pembimbingan yang dilakukan oleh pengawas sekolah meliputi semua tugas guru, dari perencanaan, pelaksanaan, penilaian dan tindak lanjutnya. Pembimbingan juga terkait dengan pengembangan profesi guru. Pada pembimbingan dalam penelitian ini difokuskan pada kemampuan guru dalam menulis hasil penelitian tindakan kelas yang dilakukan oleh guru. Pembimbingan terfokus menggunakan pendekatan kolaboratif. Digunakannya pendekatan kolaboratif karena dalam pendekatan ini memungkinkan antara pengawas dan guru dapat membuat kesepakatan menetapkan struktur proses dan kreteria dalam melaksanakan proses penelitian yang dilakukan guru (Aqib Zaenal dan Elham Rohmanto, 2007).

Penelitian tindakan merupakan alternative pengembangan dan perbaikan praktek pendidikan yang tidak hanya berbasis akademis, yaitu guru menerapkan temuan para pakar, sehingga kerja guru seperti dinilai berdasarkan criteria teori-teori yang diambil dari filsafat, psikologi dan sosiologi. Pada penelitian tindakan kinerja guru diukur melalui criteria kegitan praktek sehari-hari dalam pendidikan. Pengembangan pendidika dengan basis penelitian akademik hanay menetapkan guru sebagai objek pengembangan pendidikan, sehingga kurang memberi peran pada guru untuk memperbaiki praktek pendidikannya sendiri. (Arikunto Suharsimi, 2006). 
Pengembangan model ini sering mengakibatkan guru hanya sebagai pelaksana tanpa mengetahui secara prsis apa yang mendasari kegiatan perbaikan itu, apa yang ingin dicapai dari kegiatan itu. Penelitian akademis menempatkan pakar sebagai satu-satunya orang yang mengetahui bagaimana perbaikan pendidikan itu dilakukan sedang guru sebagai pelaksana saja. Hal ini berbeda dengan pengmbangan dan perbaikan praktek pendidikan melalui penelitian tindakan yang menempatkan guru sebagai pembaharu untuk tugas dan tanggung jawabnya sendiri dengan menggunakan criteria prakteknya yang dilakukan sehari-hari. Secara konventif kita mengenal dua jenis penelitian, yaitu penelitian kuantitatif yang sering disebut penelitian posifistic dan penelitian kualitatif. Penelitian kuantitatif menuntun peneliti untuk menguji sebuah teori sedangkan penelitian kualitatif justru membangun teori.

Pemikiran untuk melakukan upaya peningkatan Pemahaman guru dalam menyusun laporan hasil PTK berawal dari rendahnya pemahaman guru dalam menyusun laporan PTK, Pembuatan karya ilmiah merupakan bagian dari kegiatan keprofesian berkelanjutan dari guru yang wajib dilakukan. Hasil akhir yang diharapkan dari diadakannya pembimbingan terfokus dengan pendekatan kmolaboratif, adalah adanya peningkatan pemahaman para guru dalam membuat laporan hasil penelitian tindakan kelas yang dilakukannya. Secara sederhana kerangka tersebut dapat digambarkan sebagai berikut:

\begin{tabular}{|c|c|c|}
\hline $\begin{array}{l}\text { KONDISI AWAL } \\
\text { Kemampuan guru } \\
\text { dalam penyusunan } \\
\text { laporan PTK }\end{array}$ & $\begin{array}{c}\text { TINDAKAN PENGAWAS } \\
\text { MELAKSANAKAN } \\
\text { PEMBIMBINGAN } \\
\text { TERFOKUS }\end{array}$ & $\begin{array}{l}\text { KONDISI AKHIR } \\
\text { Pemahman dan } \\
\text { Kemampuan guru }\end{array}$ \\
\hline rendah. & $\begin{array}{l}\text { >Pembinaan secara kelompok. } \\
\text { >Pembinaan secara individual }\end{array}$ & $\begin{array}{l}\text { Laporan PTK } \\
\text { meningkat. }\end{array}$ \\
\hline
\end{tabular}

\section{METODE PENELITIAN}

Penelitian dilakukan di sekolah binaan peneliti, yang terdiri dari 2 sekolah, yaitu SMP Negeri 2 Sungai Melayu Rayak dan SMP Integral Ulil Albab ketapang. Pemilihan tempat penelitian, mengingat ke 2 sekolah tersebut terletak pada lokasi yang berbeda.

Penelitiaan ini adalah penelitian tindakan oleh karenanya dilaksanakan berdasarkan prinsip-prinsip penelitian tindakan di bidang pengawasan sekolah dengan menggunakan siklus-siklus tindakan. Pemberian tindakan didasarkan pada kondisi pra siklus, yakni atas dasar data dan masukan dari guru. Dari data didapatkan bahwa belum ada guru di wilayah binaan yang naik pangkat dengan menyertakan laporan hasil penelitian tindakan kelas. Masukan dari guru bahwa mereka membutuhkan pembimbingan dalam menyusun laporan hasil

penelitian tindakan kelas. (Sugiyono. 2008). Pelaksanaan penelitian dirancang dalam dua siklus tindakan, yaitu: (2) Siklus pertama, direncanakan dalam 2 pertemuan, yang berupa penjelasan secara kelompok dan bimbingan secara individu, kegiatannya terdiri dari perencanaan, pengamatan/penilaian dan refleksi. Kegiatan yang dilakukan berupa kegiatan penjelasan secara kelompok di dua sekolah. Pada pertemuan ke dua dilakukan bimbingan secara individu. Target dari tindakan pada siklus pertama adalah setelah pembimbingan kelompok dan bimbingan individu, guru memahami dan mampu membuat rencana pelaksanaan penelitian tindakan kelas. Selain memahami juga dapat melaksnakan rencana tersebut; (2) Siklus kedua dengan melaksanakan tindakan pembimbingan terfokus secara individu, yang dilaksanakan di tiap-tiap sekolah yang menjadi sasaran penelitian. dengan pendekatan kolaboratif kepada guru di sekolah binaan tentang penyusunan laporan pelaksanaan. Pada tahap ini guru diberikan bimbingan secara perorangan.

Dengan demikian dapat diketahui kesulitan yang dihadapi oleh masing-masing guru. Dari kegiatan ini diharapkan guru dapat menyusun laporan penelitian tindakan kelas, yang sesuai dengan ketentuan, sebagaimana dijelaskan pada pembimbingan secara kelompok. Adapun desain pelaksanaan penelitian sampai tersusunnya laporan hasil penelitian adalah sebagai berikut: 


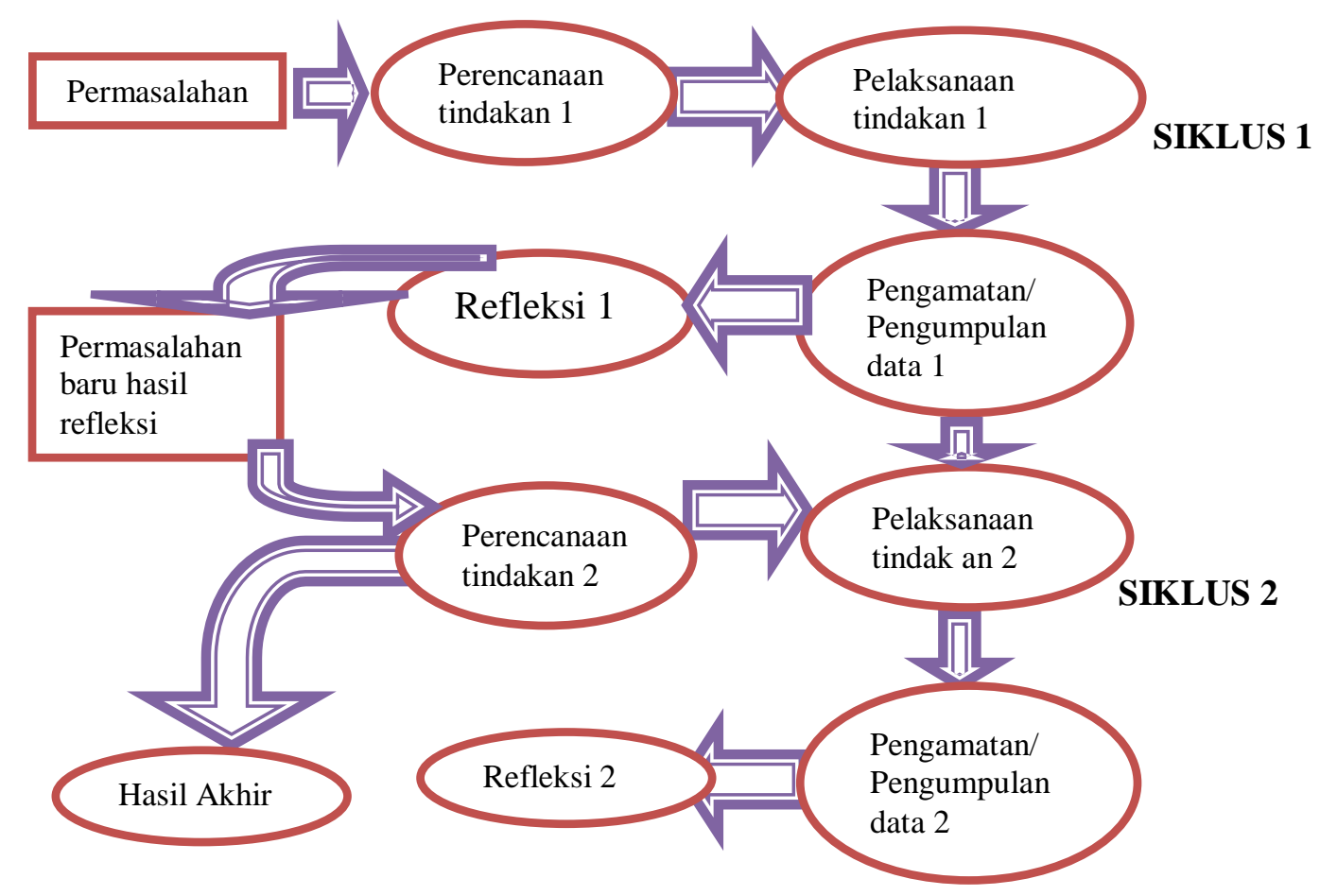

Gambar 2. Desain Penelitian Tindakan

Sebagaimana instrumen yang digunakan di atas, maka teknik pengumpulan data yang digunakan dalam penelitian ini adalah: Angket. Digunakan untuk mendapatkan data tentang pemahaman guru tentang hal-hal yang terkait dengan pemahaman guru mengenai penulisan laporan hasil PTK. Angket diberikan sebelum dan setelah guru dibimbing tentang penulisan laporan pelaksanaan penelitian tindakan kelas. Dari angket tersebut akan didapatkan peningkatan pemahaman guru tentang penulisan laporan hasil PTK. Penilaian dokumen. Digunakan peneliti untuk menilai hasil laporan yang dibuat oleh guru yang diteliti, sehingga dapat ditahui seberapa kemampuan guru dalam menyusun laporan hasil penelitian dan sekaligus diketahui seberapa keberhasilan tindakan yang dilakukan oleh peneliti.

Data dalam penelitian ini dikelompokkan dalam dua katagori, yaitu data dari penilaian laporan hasil penelitian tindakan kelas yang berbentuk angka-angka kuantitatif, dan data kualitatif yang berupa catatan-catatan hasil pengamatan selama observasi, serta angket yang diisi oleh guru. Kedua kelompok data tersebut kemudian diolah untuk memperoleh gambaran dari hasil penelitan. Penelitian tindakan sekolah ini dilakukan dengan indikator : (1) Dari guru yang dibimbing, pemahamannya tentang penulisan laporan hasil penelitian minimal $75 \%$ mencapai skor 3,50 (guru paham tentang penulisan laporan hasil PTK dilihat dari angket yang diisi oleh guru); (2) Minimal $75 \%$ guru yang dibimbing perolehan nilai laporan hasil penelitian tindakan kelasnya memperoleh skor 3,50 (baik); (3) Kegiatan yang dilakukan terlaksana sebagaimana direncanakan, dan sesuai dengan alokasi waktu yang ditetapkan

Berdasarkan landasan teori dan kerangka berpikir, dapat diajukan hipotesis tindakan sebagai berikut: "Melalui pembimbingan terfokus dengan pendekatan kolaboratif dapat meningkatkan pemahaman guru dalam menyusun laporan hasil penelitian tindakan kelas di sekolah binaan.

\section{HASIL DAN PEMBAHASAN}

\section{Hasil Penelitian}

\section{Deskripsi Kondisi Awal}

Berawal dari kondisi tersebut, memunculkan inisiatif peneliti sebagai pengawas sekolah untuk melakukan kegiatan pembibmingan kepada guru dalam menyusun laporan PTK. Pelaksanaan penelitian tindakan sekolah yang berupaya meningkatkan kemampuan guru dalam menulis laporan hasil penelitian tindakan sekolah, sebelumnya didahului dengan membagikan angket kepada guru tentang pemahaman guru tentang laporan hasil PTK. Angket diberikan kepada subjek penelitian yang dalam penelitian ini terdiri dari guru di 3 sekolah. Adapun sekolah yang 
dimaksud adalah: (1) SMP SMP Negeri 2 Sungai Melayu Rayak, sekolah ini Di Jalan Merdeka No.46/B Desa Suka Mulya, Kecamatan Sungai Melayu Rayak; (2) SMP Integral Ulil Albab Ketapang, sekolah ini terletak di Jalan
Gajah Mada, Gang Sosial, Kelurahan Sampit, Kecamatan Delta Pawan.

Berdasarkan angket yang diperoleh guru yang akan diberikan bimbingan sekaligus subjek penelitian, dengan skor sebagai berikut:

Tabel 1. Rekap Angket Pemahman Guru Sebelum Diberikan Penjelasan Tentang PTK

\begin{tabular}{cccc}
\hline No & Kode Subjek & Skor & Katagori \\
\hline $\mathbf{1}$ & G 01 & 2,1 & Kurang Paham \\
\hline $\mathbf{2}$ & G 02 & 2,1 & Kurang Paham \\
\hline $\mathbf{3}$ & G 03 & 2,1 & Kurang Paham \\
\hline $\mathbf{4}$ & G 04 & 3 & Paham \\
\hline $\mathbf{5}$ & G 05 & 1,7 & Kurang Paham \\
\hline $\mathbf{5}$ & G 06 & 3 & Kuanam \\
\hline $\mathbf{7}$ & G 07 & 2,1 & Kurang Paham \\
\hline $\mathbf{8}$ & G 08 & 2,2 & Kurang Paham \\
\hline $\mathbf{9}$ & G 09 & 2 & Paham \\
\hline $\mathbf{1 0}$ & G 10 & 3 & Kurang Paham \\
\hline $\mathbf{1 1}$ & G 11 & 2 & Kurang Paham \\
\hline & Skor total & 24,3 & \\
\hline & Skor Rata-rata & 2,2 & \\
\hline
\end{tabular}

Keterangan : (1) Skor 1,00 s/d 1,49 termasuk katagori Tidak Paham; (2) Skor 1,50 s/d 2,49 termasuk katagori Kurang Paham; (3) Skor 2,50 s/d 3,49 termasuk katagori Paham; (4) Skor 3,50 s/d 4.00 termasuk katagori Sangat Paham

Pernyataan yang diisikan dalam angket tersebut di atas, dari 11 orang guru yang dijadikan responden/ subjek penelitian, hanya 3 orang yang menyatakan paham dengan laporan penelitian tindakan kelas. Mereka yang menyatakan paham berdasarkan angket juga pada realitasnya belum pernah membuat laporan hasil penelitian yang diajukan untuk kenaikan pangkat/ jabatan guru. Apalagi mereka yang menyatakan diri belum paham dengan penelitian tindakan kelas.

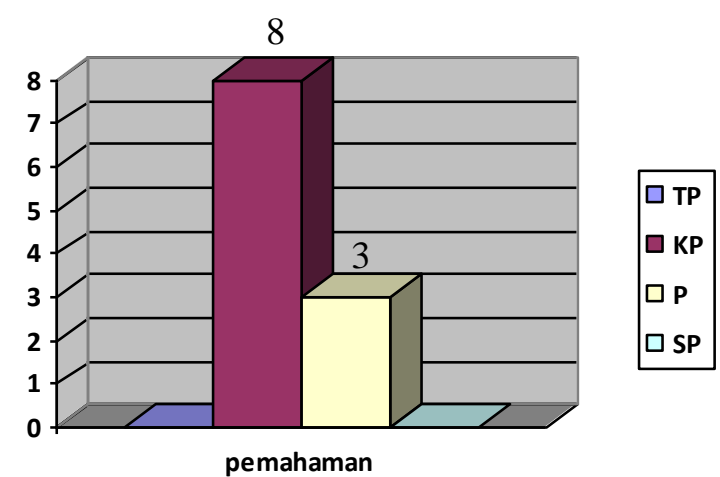

Diagram 1. Rekap Angket Pemahaman Guru Sebelum Diberikan Penjelasan Tentang PTK
Dari hasil angket yang diisi oleh para guru yang diteliti tersebut menunjukkan bahwa pemahaman guru pada hal-hal yang terlait dengan laporan penelitian tindakan kelas masih cukup rendah, yakni 2,2. Dari 11 orang guru 8 orang kurang paham tentang laporan PTK, 3 orang paham tentang laporan PTK dan tidak ada satu pun orang yang paham sekali, demikian juga yang tidak paham juga tidak ada. Para guru minimal sudah pernah mendapat sosialisasi dari Dinas Pendidikan, maupun dari Kepala Sekolah.

\section{Hasil Siklus I}

Pertemuan ke 1

Materi yang diberikan terkait dengan penulisan laporan hasil PTK sesuai dengan ketentuan Peraturan Menteri Pendayagunaan Aparatur Negara dan Reformasi Birokrasi no 16 tahun 2009. Sebelum penjelasan materi sebagai bahan guru dalam menyusun laporan hasil penelitian tindakan kelas, maka peneliti memberikan penjelasan tentang alur penelitian meliputi:(1) kegiatan penelitian dilakukan dalam 2 siklus dan dilaksanakan dalam bulan September sampai Desember 2014, (2) kepada subjek peneliti diberikan materi tentang alur penelitian PTK, bentuk laporan PTK dan cara penilaian laporan PTK. Setelah selesai pertemuan kepada guru diberikan angket tentang pemahaman guru terhadap PTK. Angket yang diberikan kepada guru dimakasudan untuk 
mendapatkan tanggapan guru tentang kegiatan yang telah dilakukan oleh peneliti, yaitu menjelaskan tentang laporan penelitian tindakan kelas. Namun harapannya secara teoritis mereka memahami, sementara untuk penulisan laporan akan diadakan pembimbingan secara kelompok kecil yang dilaksanakan di sekolah masingmasing, adapun hasil dari angket tersebut adalahsebagimana tabel sebagai berikut :

Tabel 2. Rekap Angket Isian Setelah Diberikan Penjelasan Secara Kelompok Tentang PTK

\begin{tabular}{cccc}
\hline No & Kode Subjek & Skor & Katagori \\
\hline $\mathbf{1}$ & G 01 & 2,8 & Paham \\
\hline $\mathbf{2}$ & G 02 & 3,1 & Paham \\
\hline $\mathbf{3}$ & G 03 & 3,2 & Paham \\
\hline $\mathbf{4}$ & G 04 & 3,4 & Paham \\
\hline $\mathbf{5}$ & G 05 & 3,0 & Paham \\
\hline $\mathbf{5}$ & G 06 & 3,4 & Paham \\
\hline $\mathbf{7}$ & G 07 & 3.0 & Paham \\
\hline $\mathbf{8}$ & G 08 & 3,0 & Paham \\
\hline $\mathbf{9}$ & G 09 & 3,3 & Paham \\
\hline $\mathbf{1 0}$ & G 10 & 3,3 & Paham \\
\hline $\mathbf{1 1}$ & G 11 & 2,8 & Paham \\
\hline & Skor total & 34,3 & \\
\hline & Skor Rata-rata & 3,4 & Paham \\
\hline
\end{tabular}

Keterangan : (1) Skor 1,00 s/d 1,49 termasuk katagori Tidak Paham; (2) Skor 1,50 s/d 2,49 termasuk katagori Kurang Paham

(3) Skor 2,50 s/d 3,49 termasuk katagori Paham;

(4) Skor 3,50 s/d 4.00 termasuk katagori Sangat Paham

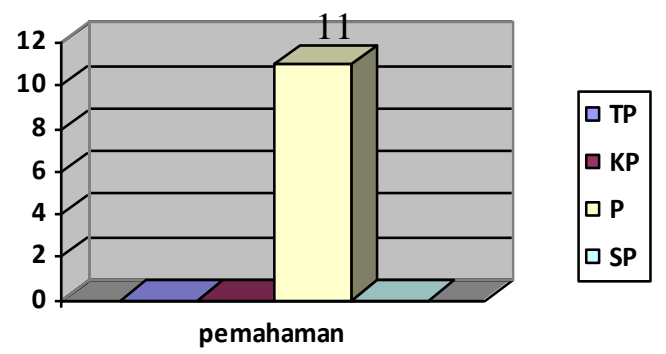

Diagram 2. Rekap Angket Pemahaman Guru Setelah Diberikan Penjelasan Secara

Refleksi : Kelompok Tentang PTK

Evaluasi terhadap tindakan pada siklus 1setelah pertemuan ke 2. Hasil pengamatan dan penilaian terhadap hasil laporan penelitian tindakan kelas yang dibuat oleh guru dapat sampaikan beberapa hal antara lain: (1) adanya peningkatan pemahaman guru terhadap PTK dengan skor pemahaman dan kemampuan guru dalam membuat laporan hasil PTK, (2) kelemahan yang terjadi pada bab I, bab IV dan bab $\mathrm{V}$, dilakukan koreksi untuk disempurnakan pada pertemuan terakhir sebagai siklus 2
Rencana yang akan dilakukan untuk kegiatan siklus 2. Meningkatkan pemahaman guru dengan melakukan tanya jawab dan menunjukkan hasil skor perolehan siklus 1 . Melakukan bimbingan kepada guru yang difokuskan pada komponen yang nilainya lemah, serta tanya jawab dengan guru, tentang komponen yang belum dikuasainya.

\section{Hasil Siklus 2}

Pengamatan dan Penilaian, setelah diadakan pembimbingan secara perorangan, kepadanya diberikan angket pemahaman pada laporan PTK. Hasil pembimbingan yang sifatnya perorangan para merasa lebih memahami komponen PTK yang sebelumnya tidak dipahami. Para guru sudah aktif menanyakan. Pada sisi lain, peneliti juga menanyakan kepada guru tentang hasil penilaian laporannya yang sudah dinilai oleh peneliti. Apabila guru tidak bertanya, maka peneliti memberikan penjelasan tentang kekurangan pada laporan yang telah disusunnya, sehingga ada komunikasi timbal balik antara guru dengan peneliti, artinya jika peneliti mengetahui kekurangan yang terdapat pada guru, maka peneliti ada inisiatif. Setelah diadakan komunikasi antara peneliti dan guru, hasilnyan adalah sebagai berikut: 
Tabel 3. Rekap Pemahaman Guru Melalui Angket Setelah Diberikan Bimbingan Secara Individu Tentang PTK

\begin{tabular}{cccl}
\hline No & Kode Subjek & Skor & Katagori \\
\hline $\mathbf{1}$ & G 01 & 3,2 & Paham \\
\hline $\mathbf{2}$ & G 02 & 3,4 & Paham \\
\hline $\mathbf{3}$ & G 03 & 3,5 & Sangat Paham \\
\hline $\mathbf{4}$ & G 04 & 3,8 & Sangat Paham \\
\hline $\mathbf{5}$ & G 05 & 3,4 & Paham \\
\hline $\mathbf{5}$ & G 06 & 3,5 & Sangat Paham \\
\hline $\mathbf{7}$ & G 07 & 3,6 & Sangat Paham \\
\hline $\mathbf{8}$ & G 08 & 3,5 & Sangat Paham \\
\hline $\mathbf{9}$ & G 09 & 3,7 & Sangat Paham \\
\hline $\mathbf{1 0}$ & G 10 & 3,8 & Sangat Paham \\
\hline $\mathbf{1 1}$ & G 11 & 3,5 & Sangat Paham \\
\hline & Skor total & 35,7 & \\
\hline & Skor Rata-rata & 3,57 & Sangat Paham \\
\hline
\end{tabular}

Keterangan : (1) Skor 1,00 s/d 1,49 termasuk katagori Tidak Paham; (2) Skor 1,50 s/d 2,49 termasuk katagori Kurang Paham; (3) Skor 2,50 s/d 3,49 termasuk katagori Paham; (4) Skor 3,50 s/d 4.00 termasuk katagori Sangat Paham

Dari data di atas dapat dilihat bahwa sebagian besar guru sudah memahami tentang laporan PTK, bahkan sebagian lainnya sudah sangat paham terhadap lapporan PTK. Berdasarkan isian angket yang dipaparkan, menunjukkan bahwa; sudah tidak ada lagi guru yang tidak paham, guru yang sudah paham sebanyak 3 orang $=27,3 \%$ dan yang sangat paham berjumlah 8 orang $=72,7 \%$. Dengan ratarata tingkat pemahaman guru terhadap laporan hasil penelitian tindkan kelas, menunjukkan bahwa target yang ditetapkan dalam kriteria ketercapaian pemahaman guru telah tercapai, karena dalam kriteria keberhasilan yang ditetapkan adalah minimal rata-rata pemahaman guru sebesar 3,50.

Setelah diadakan kegiatan siklus ke 2 dapat disampaikan hasil refleksi dapat disampaikan hal-hal sebagai berikut: (1) skor pemahaman guru terhadap laporan hasil penelilaian telah melampaui indikator yang ditetapkan, yakni rata-rata mencapai 3,57; (2) Dengan demikian kegiatan pembimbingan untuk meningkatkan pemahaman dan kemampuan guru dalam menyusun laporan hasil penelitian tindakan kelas dapat dikatagorikan telah mencapai indikator kinerja dan kriteria keberhasilan yang ditetapkan.

\section{Pembahasan}

Adapun secara ringkas pembahasannya adalah sebagai berikut Pemahaman Guru. Kondisi awal menunjukkan bahwa para guru di wilayah binaan peneliti dan menjadi sampel penelitian kondisinya variatif, ada yang sudah pernah mendapatkan sosialisasi tentang penulisan laporan PTK, ada yang belum, ada yang sudah mencoba membuat laporan tetapi belum terselesaikan, namun belum ada guru yang naik pangkat dengan mengusulkan laporan hasil PTK sebagai publikasi ilmiahnya.

Ketika diberikan angket untuk diisi kondisi awalnya menyatakan bahwa pemahaman guru pada hal-hal yang terlait dengan laporan penelitian tindakan kelas masih cukup rendah, dengan skor rata-rata 2,3. Dari 11 orang guru, sebanyak 8 orang guru kurang paham tentang laporan PTK, 3 orang paham tentang laporan PTK. Setelah diberikan penjelasan secara kelompok yang dilakukan di masing-masing sekolah, ada peningkatan pemahaman guru yang cukup signifikan. Sebelum diberi penjelasan hasil angket, skor pemahaman guru 2,3 dan setelah diberikan penjelasan skor pemahaman guru menjadi 3,4. Pembimbingan secara perorangan dapat meningkatkan pemahaman guru dari skor setelah pembimbingan kelompok sebesar 3,4 meningkat setelah pembimbingan perorangan menjadi 3,57.

Adapun perbandingan pemahaman guru sebelum dan setelah diberi bimbingan secara kelompok dan secara perorangan adalah sebagai berikut 
Tabel 4. Rekap Perbandingan Pemahaman Guru

\begin{tabular}{ccccc}
\hline No & $\begin{array}{l}\text { Kode } \\
\text { Subjek }\end{array}$ & $\begin{array}{l}\text { Skor Pemahaman Guru } \\
\text { Sebelum } \\
\text { Penjelasan }\end{array}$ & $\begin{array}{l}\text { Setelah } \\
\text { Penjelasan } \\
\text { Kelompok }\end{array}$ & Setelah Bimbingan Perorangan \\
\hline $\mathbf{1}$ & G 01 & 2,1 & 2,8 & 3,2 \\
\hline $\mathbf{2}$ & G 02 & 2,1 & 3,1 & 3,4 \\
\hline $\mathbf{3}$ & G 03 & 2,1 & 3,2 & 3,5 \\
\hline $\mathbf{4}$ & G 04 & 3 & 3,4 & 3,8 \\
\hline $\mathbf{5}$ & G 05 & 1,7 & 3,0 & 3,4 \\
\hline $\mathbf{5}$ & G 06 & 3 & 3,4 & 3,5 \\
\hline $\mathbf{7}$ & G 07 & 2,1 & 3.0 & 3,6 \\
\hline $\mathbf{8}$ & G 08 & 2,2 & 3,0 & 3,5 \\
\hline $\mathbf{9}$ & G 09 & 2 & 3,3 & 3,7 \\
\hline $\mathbf{1 0}$ & G 10 & 3 & 3,3 & 3,8 \\
\hline $\mathbf{1 1}$ & G 11 & 2 & 2,8 & 3,5 \\
\hline \multicolumn{7}{c}{ Skor total } & 22,3 & 34,3 & 3,57 \\
\hline & Skor Rata- & 2,2 & 3,43 & \\
\hline
\end{tabular}

Keterangan :

(1) Skor 1,00 s/d 1,49 termasuk katagori Tidak Paham; (2) Skor 1,50 s/d 2,49 termasuk katagori Kurang Paham; (3) Skor 2,50 s/d 3,49 termasuk katagori Paham; (4) Skor 3,50 s/d 4.00 termasuk katagori Sangat Paham

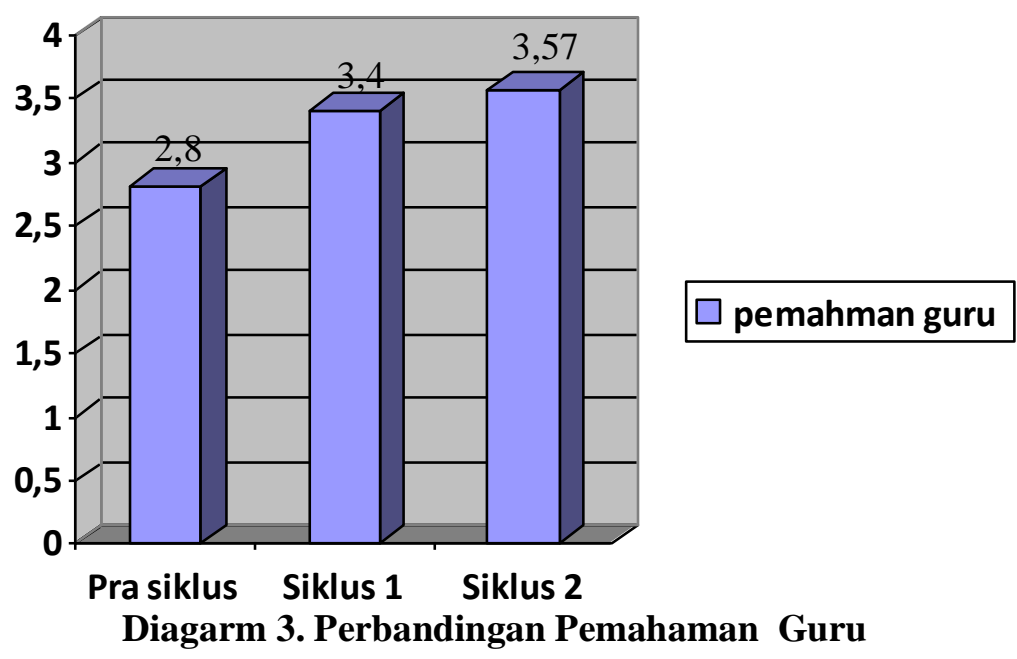

Data sebagaimana tersebut di atas menunjukkan bahwa adanya peningkatan pemahaman guru dari rata-rata 2,8 sebelum diberikan penjelasan, meningkat menjadi 3,4 setelah diberikan penjelasan secara kelompok dan meningkat lagi menjadi 3,57 setelah diberi bimbingan secara perorangan. Sebagaimana indikator yang ditetapkan, bahwa tercepainya penelitian ini adalah jika $75 \%$ guru yang diteliti mencapai tingkat pemahaman 3,50.

Tabel 5. Peningkatan Pemahaman Guru Terhadap Laporan Hasil Penelitian

\begin{tabular}{cccc}
\hline No & Siklus & Angka Kenaikan & Prosentase \\
\hline $\mathbf{1}$ & $\begin{array}{c}\text { Sebelum Penejelasan - setelah } \\
\text { penjelasan Kelompok }\end{array}$ & 2,2 menjadi 3,4 & $55 \%$ menjadi $85 \%$ \\
\hline $\mathbf{2}$ & $\begin{array}{c}\text { Setelah penjelasan kelompok - } \\
\text { setelah penjelasan perorangan }\end{array}$ & 3,4 menjadi 3,57 & $85 \%$ menjadi $95 \%$ \\
\hline
\end{tabular}


Melihat tabel sebagaimana tersebut di atas, tindakan penjelasan kelompok memberikan kontribusi kenaikan sebesar $35 \%$ dari sebelum diberikan penjelasan, sementara setelah diberi penjelasan secara perorangan mengalami kenaikan $10 \%$ dari kondisi setelah diberi penjelasan secara kelompok. Dengan demikian prosentase kenaikan pemahaman guru terhadap laporan hasil penelitian tindakan kelas, dari kondisi pra siklus sampai dengan akhir siklus 2 sebesar $40 \%$, dari semula tingkat pemahaman $55 \%$ menjadi $95 \%$.

\section{SIMPULAN DAN SARAN \\ Simpulan}

Berdasarkan data hasil penelitian di atas dapat disimpulkan sebagai berikut : (1) Melalui pembimbingan terfokus dengan teknik kolaboratif, dapat meningkatkan pemahaman guru di wilayah binaan di Kabupaten Ketapang Tahun 2013/2014 dalam menulis laporan hasil penelitian tindakan kelas, hal ini terbukti adanya peningkatan pemahaman Sebelum diberi penjelasan skor pemahaman guru 2,2 naik menjadi 3,43 setelah bimbingan secara kelompok, dan pada pembimbingan individu naik menjadi 3,57; (2) Setelah dilakukannya bimbingan dalam penulisan Penelitian tindakan kelas dengan menggunakan pendekatak kolaboratif ternyata dapat meningkatkan kemampuan guru dalam menyusun laporan penulisan PTK hal ini dibuktikan dengan hasil pada perubahan siklus I dan siklus 2 . Kemampuan guru dan kemampuan guru dalam merencanakan, melaksnakan dan menyusun laporan PTK dapat ditingkatkan dengan inservice training dengan model experiental learning. Dengan demikian dapat disimpulkan bahwa pada hakikatnya pemahaman guru dalam merencanakan, melaksanakan dan menyusun laporan PTK dapat ditingkatkan dengan berbagai upaya. Saran

Dalam rangka memberikan sumbangan pemikiran tentang peningkatan kemampuan guru dalam menyusun laporan hasil penelitian tindakan kelas, penulis menyampaikan saran sebagai berikut : (1) Sebagai salah satu syarat untuk kenaikan pangkat guru, harus mampu membuat publikasi ilmiah dan karya inovatif. Dengan melihat buku 4 dan buku 5 PKB guru dapat meningkatkan pemahamannya terhadap publikasi ilmiah; (2) Hendaknya memfasilitasi semua kegiatan guru yang mengarah kepada peningkatan kompetensi guru dalam pengembangan profesi khususnya dalam penyusunan publikasi karya ilmiah, karena penyusunan publikasi ilmiah merupakan salah satu kewajiban bagi guru; (30 Sebagai bagian dari tugas pengawas untuk melakukan pembinaan guru, maka pengawas sekolah perlu memberikan pembinaan guru untuk meningkatkan pemahaman dan kemampuannya dalam menyusun laporan hasil penelitian tindakan kelas

\section{DAFTAR PUSTAKA}

Arikunto Suharsimi, Suhardjono, Supardi. 2006. Penelitian Tindakan Kelas. PT Bumi Aksara, Jakarta.

Aqib Zaenal dan Elham Rohmanto, 2007. Membangun Profesionalisme Guru dan Pengawas Sekolah. CV Yrama Widya, Bandung.

Departemen Pendidikan Nasional. 2003. Undang Undang Republik Indonesia Nomor 20 Tahun 2003 Tentang Sistem Pendidikan Nasional, Sekretariat Jenderal Depdiknas, Jakarta.

----------, 2007. Kumpulan Permendiknas Tentang Standar Nasional Pendidikan (SNP) dan Panduan KTSP, Direktorat Pembinaan Sekolah Menengah Atas, Depdiknas, Jakarta.

---------, 2008. Petunjuk Teknis Penelitian Tindakan Sekolah. Direktorat Tenaga Kependidikan, Depdiknas, Jakarta.

----------, 2008. Laporan Penelitian Tindakan Sekolah. Direktorat Tenaga Kependidikan, Depdiknas, Jakarta.

Muh.Arifin,S.Pd.M.Pd. 2010. In Service Training model Experiential Learning untuk meningkatkan kemampuan guru SD dalam penelitian tindakan kelas. Penelitian tindakan sekolah.

Suyanto dan Asep Jihad, 2009. Betapa Mudah Menulis Karya Ilmiah. Eduka, Yogyakarta.

Sugiyono. 2008. Memahami Penelitian Kualitatafi. CV Alfabeta, Bandung 